Southern Illinois University Carbondale

OpenSIUC

Publications

Finance

$11-2009$

\title{
The Dynamics of Short-term Mutual Fund Flows and Returns: A Time-series and Cross-sectional Investigation
}

David Rakowski

Southern Illinois University Carbondale

Xaioxin Wang

Southern Illinois University Carbondale

Follow this and additional works at: http:/ /opensiuc.lib.siu.edu/fin_pubs

Published in Journal of Banking and Finance, Vol. 33, No. 11 (November 2009) at 10.1016/

j.jbankfin.2009.05.001

\section{Recommended Citation}

Rakowski, David and Wang, Xaioxin. "The Dynamics of Short-term Mutual Fund Flows and Returns: A Time-series and Crosssectional Investigation." (Nov 2009).

This Article is brought to you for free and open access by the Finance at OpenSIUC. It has been accepted for inclusion in Publications by an authorized administrator of OpenSIUC. For more information, please contact opensiuc@lib.siu.edu. 
The dynamics of short-term mutual fund flows and returns: A time-series and crosssectional investigation

David Rakowski ${ }^{\mathrm{a}^{*}}$, Xaioxin Wang ${ }^{\mathrm{b}}$

a Southern Illinois University Carbondale

${ }^{\mathrm{b}}$ Southern Illinois University Carbondale

This version: May 2, 2009

\begin{abstract}
This study analyzes the dynamics of daily mutual fund flows. A Vector Auto Regression (VAR) of flows and returns shows that the behavior of fund investors is more consistent with contrarian rather than momentum characteristics. Past fund flows have a positive impact on future fund returns, with the long-term information effect dominating the transient price-pressure effect. Seasonality in daily flows, such as day-of-week and day-of-month patterns are present, and daily flows are generally mean-reverting. Probit regressions indicate that fund investment objective, marketing policy and level of active management explain cross-sectional variation in the behavioral patterns displayed in daily flows. Our results are robust to the different methods of calculating daily flows based on whether or not the day-end TNA figures include the current-day's flow. Throughout the analysis, we contrast the dynamics of daily flows with established results for monthly fund flows and find important differences between the two.
\end{abstract}

JEL classification: G11; G23.

Keywords: Mutual funds; Fund flows; Investor behavior.

*Corresponding author. Tel.: +1 618453 1425; fax: +1 6184535626

E-mail addresses: rakowski@cba.siu.edu (David Rakowski), xwang@cba.siu.edu (Xiaoxin Wang). 


\section{Introduction and literature review}

Despite the pervasive influence of mutual fund investors on modern financial markets, most research on short-term investment decisions focuses on the behavior of investors who directly own securities ${ }^{1}$ and not those who invest through the intermediary of a mutual fund. Studies that do examine behavior in the context of mutual funds look mostly at the behavior of fund managers ${ }^{2}$, or at the investors' long-term net purchases and sales of fund shares ${ }^{3}$. The short-term behavior of mutual fund investors is a research area that remains underexplored.

Individual investors who directly trade securities are well documented to exhibit seemingly irrational behaviors such as over confidence, excessive trading, the tendency to sell winning stocks too soon and to hold on to losing stocks too long, and the disproportional buying of attention-grabbing stocks, which generally lead to a negative impact on their investment performance (Barber and Odean, 2000, 2008). The unique features of open-end mutual funds provide a useful context in which to examine the behavior of individual investors who trade through mutual funds. The net purchases or sales of fund shares by investors are referred to as 'flows.' Short-term mutual fund flows are dominated by individual households (ICI, 2008). Funds provide standardized information and liquidity features while individual securities do not. Furthermore, because flows are always initiated by investors, there is no counterparty action to identify and consider. Mutual fund flows therefore provide a valuable tool for studying the investment decisions of individual households.

\footnotetext{
${ }^{1}$ See for example, De Long, Shleifer, Summers and Waldmann (1991), Barber and Odean (2000, 2008).

${ }^{2}$ See for example Brown, Harlow and Starks (1996) and Chevalier and Ellison (1999).

${ }^{3}$ See for example Sirri and Tufano (1998), Jain and Wu (2000), and Cashman, Nardari, Deli and Villupuram (2008).
} 
Institutional investors, such as mutual fund managers, are perceived as suffering much less from irrational behavioral tendencies (Shapira and Venezia, 2001). However, the trading decisions of mutual fund investors are known to impact the constraints of the fund manager (Edelen, 1999). Therefore, studying the short-term fund flows is important both in understanding the behavioral trends of fund investors, as well as in their potential impact on the actions of fund managers.

Existing theoretical models of fund flows do not specify the time frame over which flow dynamics are relevant (Berk and Green, 2004). However, Investors who trade securities through mutual funds are documented to act as momentum traders (Sirri and Tufano, 1998) at monthly or quarterly frequencies, with conflicting evidence as to the relationship between their flows and future fund returns (Friesen and Sapp, 2007; Frazzini and Lamont, 2008).

With regards to investor behavior and daily fund flows, empirical research has only touched on the determinants of daily flows, largely through studies that examine specific anomalies that arise in the trading of mutual fund shares. Examples include examinations of the NAV mispricing impact on daily flows (Chalmers, Edelen and Kadlec 2002; Greene and Hodges, 2002) and the associated opportunities for markettiming trades. At the individual account level for a single S\&P 500 index fund, Goetzmann and Massa (2002) show that there exist investors who follow both momentum and contrarian behavior patterns. Johnson (2007) aggregates daily data over each month at the individual account level in order to examine differences between old and new shareholder flows. On a more general level, Edelen and Warner (2001) examine 
the properties of aggregate daily flows, but do not consider cross-sectional variation across individual funds.

In this paper, we perform an in-depth examination of the time-series and crosssectional patterns in daily mutual fund flow and its dynamic interaction with daily fund returns. We investigate if investors who trade securities through mutual funds share the same properties previously documented by those who invest directly, and whether the short-term behavior of these mutual fund investors matches the patterns displayed by long-term flows.

This study provides valuable extensions to our understanding of investor behavior, market liquidity, and portfolio management. Our results indicate that on a daily basis, mutual fund investors act more consistently with contrarian rather than momentum strategies. Daily flows are usually mean-reverting in aggregate, although there exists considerable variation across funds. We further classify when fund investors act consistent with contrarian or momentum trading patterns, and when mutual fund flows demonstrate persistence or mean-reversion. We find that fund investment objectives, the liquidity of fund holdings, fund marketing policies and fund trading activities are all important in explaining the behavioral patterns present in daily flows. In addition, both the day of the week and the day of the month lead to significant differences in daily flows. Past flows have a positive impact on future returns with an information effect rather than the price pressure effect driving this link. Our results are robust to alternative methods of computing daily fund flows, and whether or not the day-end TNA figures include the current-day's flows. The findings suggest that mutual fund investors act somewhat differently from those who trade securities directly, and daily patterns of fund 
flows and the daily interaction of fund flows and returns are different from those at monthly and quarterly frequencies.

The rest of the paper proceeds as follows. Section 2 explains the characteristics of our data and methodology, including some computations that are unique to daily mutual fund flow data. Section 3 presents the methodology and results. Section 4 concludes.

\section{Data and daily flow calculations}

We obtain daily mutual fund data from Lipper. Lipper provides fund total net assets (TNA) and returns (adjusted for distributions) from March 2000 to October 2006, both of which are used to calculate daily flows. Funds are required to have at least 250 valid daily observations to be included in the sample. We put the data through rigorous screens for errors, eliminating extreme observations (top and bottom $1 \%$ of flows), while also adjusting for possible reporting inconsistencies. All observations resulting from mergers, liquidations, and splits are deleted. We delete all funds with average daily TNA of less than $\$ 10$ million due to the extremely erratic nature of percentage flows for these funds. To compare with daily data, we also obtain monthly TNA, returns, and fund characteristics from the CRSP mutual fund database for each year of our sample period. Our sample includes approximately 6,772 funds with an average of about 948 daily observations each, for a total of 6,419,100 daily observations. Our monthly flow calculations from CRSP yield 287,740 monthly observations, or about 42 monthly observations per fund. Different share classes of the same fund are treated as separate funds due to the different flows, loads and fees of each share class. 
Daily net flow into a mutual fund is the change in its end-of-day TNA, adjusted for the return over the prior day. Unfortunately, funds do not possess consistent day-end TNA figures. Some funds report TNA including the current day's flows, some funds do not, and other funds report TNA partially including the day's flows, with the remaining flows being included in the next day's TNA. We respond to this inconsistency by using three different measures to compute daily flows.

Using Method 1, we compute flows assuming that day $t$ flows are not included in the reported closing TNA on day $t$. Therefore, the closing TNA on day $t$ plus the dollar amount of flow for day $t$, denoted as $\$$ flow $w_{t}$, grow together at the rate $r_{t+1}$ to the closing TNA on day $t+1$.

$$
\left(\$ \text { flow }_{t}+T N A_{t}\right)\left(1+r_{t+1}\right)=T N A_{t+1}
$$

Our formula for the dollar amount of daily fund flow is thus:

$$
\text { slow }_{t}=\frac{T N A_{t+1}}{\left(1+r_{t+1}\right)}-\text { TNA }_{t}
$$

Percentage fund flows would then be computed by dividing $\$$ flow by the TNA as of the beginning of day $t$. The TNA at the start of day $t$ is computed by discounting the end of day $t$ TNA by the return on day $t$. Therefore, percentage flows ${ }^{4}$ are computed as:

$$
\% \text { flow }_{t}=\frac{\text { Sflow }_{t}}{\left(\frac{\text { TNA }_{t}}{\left(1+r_{t}\right)}\right)}
$$

Method 2 assumes that daily flows are included in the day-end TNA. If the reported TNA includes the current day's net flow, then TNA at the end of day $t-1$ grows

\footnotetext{
${ }^{4}$ Even though the amount of bias in daily calculations should be extremely small, we repeat all analysis using end-of-period TNA to compute percentage flows. This leads to no major changes in our findings.
} 
at rate $r_{t}$, plus the dollar flow at day $t$, should equal to TNA at the end of day $t$. Therefore, we have:

$$
\begin{aligned}
& \operatorname{TNA}_{t-1}\left(1+r_{t}\right)+\$ \text { flow }_{t}=T N A_{t} . \\
& \text { flow }_{t}=T N A_{t}-T N A_{t-1}\left(1+r_{t}\right) .
\end{aligned}
$$

To compute percentage flows, we then discount by the TNA at the beginning of day $t$, which is equal to the TNA at the end of day $t-1$ :

$$
\% \text { flow }_{t}=\frac{\$ \text { flow }_{t}}{T N A_{t-1}} \text {. }
$$

In Method 3, we sum daily dollar flows, $\$$ flow $_{t}$, for each fund each month by each previous method to compute cumulative daily flow each month. We then match the cumulative daily flow each month with the CRSP monthly flow to determine which method (1 or 2 ) applies best to each fund each month. Because CRSP includes the current month's flow in the end-of-month TNA, we use Method 2 to compute monthly fund flows from the CRSP data. This follows almost all other papers that examine monthly mutual fund flows, such as Sirri and Tufano (1998). Our matching algorithm results in a total of 2,190,395 daily observations (34\%) being matched to Method 1. A total of 4,228,705 daily observations (66\%) are matched to Method 2.

Table 1 describes the characteristics of daily fund flows computed by each of our three methods. Method 2 leads to a higher level of daily flows, although Method 1 yields higher absolute flows on average, consistent with repeated sign changes for flows when using Method 1. The different daily flow estimations from the three different methods highlight the importance of calculating daily flows correctly and warrant the use of 
Method 3. Overall, the daily figures from Method 3 provide statistics that are most consistent with the long-term characteristics of fund flows (ICI, 2008) ${ }^{5}$.

\section{Methodology and results}

3.1. Interaction between mutual fund flows and returns: A vector auto regression (VAR) approach

To examine if mutual fund investors follow momentum or contrarian strategies, we need to investigate the interaction between fund returns and future flows. If investors chase hot funds, then flows will be positively related to lagged returns, and these investors are classified as momentum traders. When flows are preceded by negative returns, then the mutual fund's investors act as if they are buying funds that have suffered a price drop but selling funds whose price have risen, and therefore they are classified as contrarian traders.

To investigate if there is a positive or negative impact from fund flows on fund returns and whether this impact is due to price pressure or information, we need to examine the relationship between fund flows and future returns. If there exists a positive impact from past flows on future returns, then the persistence of the impact indicates a long-term information effect, while reversion in the impact points to a short-term pricepressure effect.

\footnotetext{
${ }^{5}$ Average daily flows, arithmetically compounded over the year, yield between $1 \%$ and $6 \%$ growth in fund assets annually. This is of similar magnitude as annualized returns (about 5\%) over our sample period. Furthermore, the absolute value of daily flows demonstrates that trading costs and related management efforts are likely to be non-trivial. The absolute value of daily flows is close to 50 basis points, which would yield a turnover of roughly $125 \%$ of a fund's assets per year. Even though some of these flows could be netted out over short time periods (Johnson, 2007), there likely still remains a significant fraction that must influence the capacity constraints of the portfolio manager.
} 
A VAR structure best captures the potential interactions between the leads and lags of return and flow, and is hence more appropriate than OLS regressions or regressions alike which are set up for returns and flows separately. We model the Vector Auto Regression (VAR) between daily mutual fund returns $\left(r_{t}\right)$ and flows $\left(f_{t}\right)$ as follows

$$
\left[\begin{array}{l}
r_{t} \\
f_{t}
\end{array}\right]=\left[\begin{array}{l}
\alpha_{1} \\
\alpha_{2}
\end{array}\right]+\sum_{p=1}^{5}\left[\begin{array}{ll}
\beta_{11, p} & \beta_{12, p} \\
\beta_{21, p} & \beta_{22, p}
\end{array}\right]\left[\begin{array}{c}
r_{t-p} \\
f_{t-p}
\end{array}\right]+\left[\begin{array}{l}
\varepsilon_{1, t} \\
\varepsilon_{2, t}
\end{array}\right]
$$

Five lags are chosen because it conforms to the average number of trading days in a week. The VAR(5) model is estimated for each of the funds in the sample.

The reported numbers in Table 2 are the cross-sectional averages of the coefficient estimates, their t-values, and the percentages of significant positive and negative estimates at the 95\% level. Panel A shows that while for $39 \%$ (25\%) of the funds there is a significant negative impact from $r_{t-1}\left(r_{t-2}\right)$ on the current day's flow, significant positive coefficient estimates are found for only $13 \%(7 \%)$ of the funds. The result suggests that more mutual fund investors are following a strategy consistent with short-term contrarian behavior than with momentum behavior. Mutual fund investors, on a daily basis, do not chase hot funds as they do over the long-term. Rather, the contrarian behavior is similar to the negative-feedback trading practiced by some direct individual investors. This implication is further explored in Section 3.4. as we distinguish funds according to cross-sectional characteristics.

For comparison, we also run a VAR model on monthly mutual fund flows and returns. The model is identical to the daily VAR with the only exception being the number of lags. Since there are 12 months in a year, we choose a lag of 12 for the monthly VAR. 


$$
\left[\begin{array}{l}
r_{t} \\
f_{t}
\end{array}\right]=\left[\begin{array}{l}
\alpha_{1} \\
\alpha_{2}
\end{array}\right]+\sum_{p=1}^{12}\left[\begin{array}{ll}
\beta_{11, p} & \beta_{12, p} \\
\beta_{21, p} & \beta_{22, p}
\end{array}\right]\left[\begin{array}{l}
r_{t-p} \\
f_{t-p}
\end{array}\right]+\left[\begin{array}{c}
\varepsilon_{1, t} \\
\varepsilon_{2, t}
\end{array}\right]
$$

The results of our analysis at a monthly frequency are presented in Table 2, Panel B and D. Our data show that there are very few statistically significant lead-lag relationships between monthly mutual fund flows and returns. Among the 15,082 funds, only $13 \%$ of them have a significant positive relationship between the fund return of the previous month and the net flows into the fund during the current month. For all the other return-flow cross terms, less than $10 \%$ of the funds have statistically significant coefficients between returns and lagged flow or vice versa.

The VAR model also allows us to examine the impact of past flows on future returns. The results for daily data, presented in Table 2 Panels C, show that daily mutual fund returns are positively affected by past flows. $45 \%$ of the funds see a significant positive reaction of fund returns to the previous day's flows, while $61 \%$ of the funds see it from the flow of day $t-2$, and the positive significant effect on day $t$ returns remains for $42 \%$ of the funds when day $t-3$ flows are examined. On the contrary, the percentage of funds that experience a significant negative impact from day $t-1, t-2$ and $t-3$ flows to day $t$ returns is only $4 \%, 1 \%$ and $2 \%$ respectively.

The positive link between returns and lagged flows could be due to either a permanent information effect or a temporary price pressure impact. If the effect is permanent then we would expect to see the significance of lagged flows gradually decrease to zero at greater lags. If the effect is due to temporary price pressure, then we should expect to see the impact reverse after several days, with lagged flows taking significant negative coefficients. Our findings are consistent with the permanent information impact of flows because the coefficients on lagged flow generally decrease in 
significance as the lags increase to 3,4 and 5 , with only very weak evidence of a possible reversal at lag 5. In contrast to the daily results, Table 2 Panel D shows almost no relation between flow and future returns for monthly data. This is consistent with other research such as Cashman, Nardari, Deli and Villupuram (2008) and provides another example of the unique characteristics of daily flow data.

\subsection{Time-series properties of mutual fund flows: Autocorrelation and seasonality}

The VAR model also allows us to examine the autocorrelations in mutual fund flows and returns themselves. From Table 2 Panel C, we can see that daily fund returns shows a large degree of positive autocorrelation in that $44 \%$ of the funds have positive and significant $1^{\text {st }}$ order autocorrelations and $32 \%$ show $2^{\text {nd }}$ order positive significant autocorrelation. Positive autocorrelation in mutual fund returns is consistent with previous research (Chalmers, Edelen and Kadlec, 2002; Greene and Hodges, 2002) and can be partially explained by the use of "stale" prices in computing day-end NAVs.

Daily flow also demonstrates autocorrelation, except that it is negatively correlated. Table 2 Panel A shows that approximately $74 \%$ of the funds show a $1^{\text {st }}$ order negative and significant autocorrelation in flows and $55 \%$ of the funds display significant negative $2^{\text {nd }}$ order autocorrelation ${ }^{6}$. This result is consistent with the aggregate findings of Edelen and Warner (2001) over the 1998-1999 time period with an independent database. From lag 3 and on, the autocorrelations in daily fund flows are significant in no more than $25 \%$ of the funds. The mean-reverting feature of daily flows is generally not shared at the monthly level. Table 2 Panel B shows that except for $18 \%$ of the funds

\footnotetext{
${ }^{6}$ The first and second order negative autocorrelation in daily fund flows are also presented in a simple AR (5) model on daily fund flows. For space conservation, the AR(5) results are not reported but available upon request.
} 
showing positive and significant $1^{\text {st }}$ order autocorrelation in monthly flows, autocorrelations at other lags are significant for less than $8 \%$ of the funds ${ }^{7}$. The clear difference in the behavior of monthly flows from daily flows suggests that different forces are driving flows at shorter frequencies, justifying our detailed analysis of daily flows.

Some factors that impact fund flows change over time but are common to all funds are liquidity driven, such as seasonal patterns which include day-of-the-week effects and day-of-the-month effects. Arguments in support of these effects include the evidence that individual investors demonstrate predictable patterns in their trading behavior based on the time of week (Doyle and Chen, 2009; Venezia and Shapira, 2007) and stock volume shows changes around the turn of the month (Ariel, 1987), as well as the intuitive argument that inflows from automatic contributions in pension accounts occur around the change of month.

We examine fund flow seasonality in Table 3. We find that there are outflows at the beginning of the month and there are higher percentage inflows at month end. Absolute flows are slightly higher at both the beginning and end of the month than midmonth. These results are intuitive, in that contributions and redemptions from managed

\footnotetext{
${ }^{7}$ Other studies of the time-series properties of long-term fund flows, such as Johnson (2007) and Cashman, Nardari, Deli and Villupuram (2008) find stronger positive autocorrelation when inflows and outflows are considered separately over longer time periods. These stronger results are obtained through FamaMacBeth, SUR, or pooled regressions, while we run a fund-by-fund VAR. Cao, Chang and Wang (2008) also adopt the VAR approach and find that aggregate fund flow is negatively related with market volatility. To further check the results from our VAR models above, we also run the return and flow regressions separately as conventionally done within a panel regression framework. For daily data, the following regressions are run: $R_{t}=\alpha+\beta_{1} R_{t-1}+\ldots+\beta_{5} R_{t-5}+\delta_{1} F_{t-1}+\ldots+\delta_{5} F_{t-5}+\mu_{t}$ and $F_{t}=\alpha+\beta_{1} R_{t-1}+\ldots+\beta_{5} R_{t-5}+\delta_{1} F_{t-1}+\ldots$ $+\delta_{5} F_{t-5}+\mu_{t}$. For monthly data, the same regressions are run with 12 lags. The results (available upon request) are stronger than VAR results because the panel data pools observations across funds, which increases the power of statistical tests. These findings suggest caution in the interpretation of mutual fund flow analysis that is conducted over a cross-section of funds in a panel regression framework without specific attention paid to the dynamic lead-lag interaction between flows and returns, as captured by a VAR.
} 
accounts $^{8}$, such as pensions, are likely to be made at the turn of the month. Across the days of the week, absolute flows are higher on Fridays, suggesting that the volatility of flows increases at the end of the week. The finding of significant patterns across the week is in contrast to the aggregate analysis of Edelen and Warner (2001) ${ }^{9}$.

\subsection{Cross-sectional variation in the average level of flow}

After documenting the time-series features of daily fund flows and returns, we turn to the examination of cross-sectional variation in the level of daily flows. Table 4 provides descriptive statistics of the cross-sectional characteristics. As we can see, there is a significant difference in dollar flows among domestic bond funds, domestic equity funds and international equity funds. During our sample period, domestic bond funds experience an average of over $\$ 12,000$ in outflow per day while domestic equity funds have over \$16,000 of inflow and international equity funds have average inflows of over $\$ 86,000$. The huge inflow to international equity funds is consistent with the high average returns they offer, 2.9 basis points per day vs. 2.0 basis points per day for domestic bond funds. As a result, international equity funds also have the highest percentage daily flows and percentage absolute daily flows.

To investigate what factors cause the differences in flows among different types of funds, we adopt a cross-sectional regression of fund flows on fund characteristics.

$$
\begin{aligned}
& \text { Dependent }_{i}=\alpha+\beta_{0} \text { RETURN }_{i}+\beta_{1} \text { RETURN }_{i}^{2}+\beta_{2} 12 \mathrm{~B} 1_{i}+\beta_{3} \mathrm{NON}_{12 B 1_{i}+\beta_{4} \mathrm{FRONT}_{i}+} \\
& \beta_{5} \text { DEFERRED }_{i}+\beta_{6} \text { TURNOVER }_{i}+\beta_{7} \text { SIZE }_{i}+\beta_{8} A G E_{i}+\beta_{9} \text { Family }_{i}+e_{i},
\end{aligned}
$$

\footnotetext{
${ }^{8}$ Further tests indicate that these patterns exist for both institutional and retail accounts. Therefore, it is not solely automatic contributions to institutional accounts driving these patterns across the month.

${ }^{9}$ Our results for these patterns across the week and month persist if we include dummy variables in a AR(5) regression of daily flows (not reported).
} 
The dependent variable is first the mean daily percentage flow and then, the mean absolute daily percentage flow. Return on a fund is the average daily return reported by Lipper. Gruber (1996) and Sirri and Tufano (1998) both document that flows into the very top performing funds are greater, and to account for this nonlinearity, we add a squared term for returns in the regression. Expense ratios are decomposed into marketing (12B1) and management (NON12B1) components. Load fees are classified as FRONT or DEFERRED. Fund SIZE is the natural logarithm of a fund's average daily TNA. The size of a fund's family (FAMILY) is computed as the number of funds in the fund family ${ }^{10}$. Fund $A G E$ is the number of years from the inception of the fund. Fund TURNOVER ratio is used as a measure of a fund's potential transaction cost. Our sample is restricted to Domestic Equity, International Equity, and Domestic Bond funds.

The variables chosen above are related to factors which are known to drive the behavior of flows at longer frequencies, or which are important control variables in any examination of fund flows. These include the fund's performance (Sirri and Tufano, 1998; Berk and Green, 2004), its marketing policies (Jain and Wu, 2000), or its trading behavior (Wermers, 2000). Management expenses could be positively related to performance and thus to flows (Berk and Green, 2004) while marketing expenses (12b-1 fees and loads) lower investors' search costs and make it easier for them to obtain information about a fund's potential performance (Sirri and Tufano 1998; Jain and Wu 2000). Older funds have more information available about past performance providing

\footnotetext{
${ }^{10}$ The size of a fund's family (FAMILY) is computed in two ways. First, we take the sum of the TNA of all funds in the fund's family, minus the TNA of the current fund. Second, we take the number of funds in the fund family, not including the current fund. Because both methods yield similar results in explaining daily fund flows, we report results only for the number of funds in the fund family.
} 
useful information about the skill of its managers (Berk and Green 2004; Chevalier and Ellison, 1999).

Table 5 reports the summary statistics ${ }^{11}$ on the explanatory variables-fund characteristics. Compared with domestic equity funds and international equity funds, domestic bond funds have older age but smaller size, and higher turnover, as well as lower fees and loads. These sample characteristics, including the higher turnover for bond funds, are similar to other samples taken from the CRSP mutual fund database (Rakowski, 2009; Jayaraman, Khorana, and Nelling, 2002).

Table 6 Panel A, presents the results of the cross-sectional regressions with mean daily percentage flows as the dependent variable. The positive and significant coefficient on RETURN is consistent with a positive flow-performance relationship in the crosssection, in that funds with higher average returns have higher inflows on average. We also see strong evidence of the nonlinear nature of this relationship, with $R E T U R N^{2}$ being highly significant for domestic equity and international equity funds. This nonlinearity is consistent with previous findings that inflows to mutual funds are stronger for extremely high-performance funds. The positive and significant coefficient for $12 B 1$ fees suggests that advertising is effective in increasing daily flows on average, and is consistent with other examinations of mutual fund advertising (Jain and Wu, 2000; Barber, Odean and Zheng, 2005). FRONT load is positive and significant only for domestic equity funds and DEFERRED load are all negative and significant, indicating investors' unwillingness to invest in to funds that will charge them upon redemption. The negative and significant coefficient for fund AGE is consistent with Berk and Green’s (2004) model of decreasing

\footnotetext{
${ }^{11}$ Data is now averaged across funds rather than across all observations, leading to slight differences from Table 4 for some variables.
} 
economies of scale arising as funds age. The results are generally consistent across domestic equity, domestic bonds and international equity funds. NON12B1, TURNOVER and the size of the fund FAMLY are consistently insignificant across all three types of funds, though fund SIZE is positive and significant for the equity funds.

Table 6 Panel B presents the regression results with mean absolute daily flows being the dependent variable. Overall, the results are similar as in Panel A. One major difference is that fund SIZE turns significant negative for all funds, indicating large funds have more stable flows. NON12B1, TURNOVER and the size of the fund FAMLY also turn significant for certain types of funds. The significant and positive TURNOVER coefficient could be explained by larger absolute fund flows causing more trading by fund managers. Similarly, fund family SIZE is significantly positive for both domestic and international equity funds, which are more susceptible to market-timing than fixedincome funds. Interestingly, the equity funds with higher RETURN have a higher level of fund flows, while bond funds with higher RETURN have subdued flow activity.

\subsection{Probit regression of cross-sectional variation in flow characteristics}

The dynamics of daily fund flows from the VAR analysis in Table 2 reveal that at a one-day lag, 39\% of the funds have investors who appear to follow contrarian patterns on average, while $13 \%$ have momentum investors. $74 \%$ of the funds have meanreverting flows while $5 \%$ of them show persistent flows. To examine what factors cause these differences across funds, we examine cross-sectional variation in flow patterns by running a set of four Probit regressions. 
indicator $_{i}=\beta_{0}+\beta_{1} 12 \mathrm{~B} 1_{i}+\beta_{2}{\mathrm{NON} 12 \mathrm{~B} 1_{i}+\beta_{3} \text { FRONT }_{i}+\beta_{4} \text { DEFERRED }}_{i}$

$+\beta_{5}$ TURNOVER ${ }_{i}+\beta_{6}$ SIZE $_{i}+\beta_{7}$ FAMILY $_{i}+\beta_{8} A G E_{i}+\beta_{9}$ IntlEquity $_{i}+$

$\beta_{10}$ DomesticBond $_{i}+\beta_{11}$ LargeGrowth $_{i}+\beta_{12}$ LargeValue $_{i}+\beta_{13}$ SmallGrowth $_{i}+$

$\beta_{14}$ SmallValue $_{i}+e_{i}$

In the first (second) model, indicator takes a value of 1 if the coefficient estimate on flow at lag 1 was positive (negative) and significant in the flow equation in our VAR model, i.e., persistent flow (mean-reverting flow). In the third (fourth) model, indicator takes a value of 1 if the coefficient estimate on returns at lag 1 was positive (negative) and significant in the flow equation in the VAR model, i.e., momentum trading (contrarian trading). Taken together, we use these traits to examine patterns in the overall predictability of a fund's flows. We consider flows to be predictable for a fund if any of the above indicator variables is equal to one.

Our explanatory variables are the same as those in the cross-sectional analysis in Section 3.3., except that we omit the fund's average return and squared return due to endogeneity that could be introduced to our model. Instead of running the four sets of Probit models for each type of fund, we include dummy variables for international equity, domestic bond and domestic equity funds into the regressions. Domestic equity funds are further classified according to the four "corners" of Morningstar 3x3 style box: smallcap, mid-cap or large-cap based on the capitalization of holdings, cross with value, core or growth orientation of the holdings.

Results from the Probit regressions ${ }^{12}$ are presented in Table 7. Flow persistence is less likely for older funds holding large-cap stocks, consistent with market timing

\footnotetext{
${ }^{12}$ Because the dependent variable takes on a value of 1 or 0 , the magnitude and the sign of a coefficient estimate is directly related to the probability of the dependent variable being 1 or 0 , we therefore report the coefficient estimates and their significance levels with the understanding that if an $\mathrm{N}$-way Probit model is performed, coefficient estimates will not directly relate to the probability of a certain event.
} 
being less common for these funds. Flow reversals are more likely for funds with low management fees, as intuitively, mean-reverting flows require less managerial effort. Both reversals and persistence are more likely for front-load funds in large fund families. Therefore, the common factors indicating overall predictability of flows are tied to a fund's marketing policies, with the liquidity cost (or the associated broker advice) of front-end loads and the marketing features of a large fund complex making systematic patterns in flows more likely.

Consistent with trend chasing on the part of investors being associated with active portfolio management, we find that both management fees and turnover are positively related to the chances of a momentum pattern, but negatively related to contrarian behavior. As with our earlier finding for reversals, we now find that both front and deferred loads make contrarian patterns more likely, consistent with the flow-suppressing liquidity cost of the fees, or with the moderating influence of broker advice. Larger funds are more likely to display momentum trading, which could indicate a reversal of causality. That is, funds with large numbers of momentum investors will tend to have grown to a larger size. Consistent with trend chasing in specialized investment objectives, we find momentum more likely for international, small-cap equity, and bond funds, and less likely for large-cap stock funds. Overall, funds susceptible to trend chasing behavior on the part of investors are more likely to experience momentum patterns in flow, while funds with more sophisticated marketing structures have more predictable flows.

\section{Conclusions}


In this paper, we examine the time-series properties of daily mutual fund flows, the dynamic interaction between daily fund flows and returns, and the patterns of crosssectional variation and predictability in those flows. Overall, our results highlight the difference between mutual fund investors and investors who trade securities directly, and the short-term vs. long-term difference in fund flows and in the interaction between fund flows and fund returns.

We find that fund investors have contrarian behavioral tendencies at a daily level, opposite of what we would expect based on the flow-performance relationship found in studies of long-term mutual fund performance. It seems that there are very different factors driving the behavior of mutual fund investors at short frequencies, as opposed to the longer term. When the influence of past flows is considered, we observe significant negative auto-correlation of daily flows at short lags. Again, this is the opposite of the strong momentum that is reported for fund flows at monthly intervals. A Probit model indicates that variation in the dynamics of daily fund flows is explained by a fund's marketing policies, investment objectives, and level of active management.

Daily fund flows are also positively related with future fund returns, and information, rather than price pressure, seems to drive this result. This positive relation implies that the short-term decisions of fund investors are rationally timed, while individual investors who trade securities directly have been documented as sometimes acting irrationally. There exist predictable patterns as to which funds experience behaviorally motivated trading, with high-fee small-cap funds more likely to experience the persistent and/or momentum trading patterns that characterize trend chasing on the part of investors. The higher fees charged in response to behaviorally motivated flow is 
consistent with capital market equilibrium in the market for fund management services. An open question is whether the overall level of flows that we observe is, in fact, optimal. This question, while interesting, is beyond the scope of the current study and warrants future investigation.

We show that past flows, returns, the day-of-the-week, the-time-of-month, and fund characteristics are all important in explaining the level of daily flows. These results indicate that mutual fund investors do not trade simply based on exogenous liquidity needs. They respond dynamically to information about a fund and channel their investments to those funds for which information is available and performance is higher. While the underlying motivation for fund investors appears consistent with documented behavioral tendencies, the patterns across funds suggest that there exists a wide and predictable range of flow profiles that is systematically related to a fund's investment objectives, marketing structure, and life-cycle. Our documentation of these patterns can be incorporated into any future examination of investor behavior in the presence of the unique liquidity and informational features of an open-end mutual fund, as well as in judging the potential flow-induced liquidity costs faced by a particular fund manager. 


\section{References:}

Ariel, R., 1987. A monthly effect in stock returns. Journal of Financial Economics 18, 161-174.

Barber, B., Odean, T., 2000. Trading is hazardous to your wealth: The common stock investment performance of individual investors. Journal of Finance 55, 773-806.

Barber, B., Odean, T., 2008. All that glitters: The effect of attention and news on the buying behavior of individual and institutional investors. The Review of Financial Studies 21, 785-818.

Barber, B., Odean, T., Zheng, L., 2005. Out of sight, out of mind: The effects of expenses on mutual fund flows. The Journal of Business 78, 2095-2120.

Berk, J., Green, R., 2004. Mutual fund flows and performance in rational markets. Journal of Political Economy 112, 1269-1295.

Brown, K., Harlow, W., Starks, L., 1996. Of tournaments and temptations: An analysis of managerial incentives in the mutual fund industry. Journal of Finance 51, 85-110.

Cashman, G., Nardari, F., Deli, D., Villupuram, S., 2008. Understanding the non-linear relation between mutual fund performance and flows. Working paper, Texas Tech University.

Chalmers, J., Edelen, R., Kadlec, G., 2002. On the perils of financial intermediaries setting security prices: The mutual fund wild card option. Journal of Finance 56, 22092236.

Cao, C., Chang E., Wang, Y., 2008. An empirical analysis of the dynamic relationship between mutual fund flow and market return volatility. Journal of Banking \& Finance 32, 2111-2123.

Chevalier, J., Ellison, G., 1999. Are some mutual fund managers better than others? Cross-sectional patterns in behavior and performance. Journal of Finance 54, 875-899.

De Long, J., Shleifer, A., Summers, L., Waldmann, R., 1991. The survival of noise traders in financial markets. Journal of Business 64, 1-19.

Doyle, J., Chen, C.H., 2009. The wandering weekday effect in major stock markets. Journal of Banking and Finance 33, 1388-1399.

Edelen, R., 1999. Investor flows and the assessed performance of open-end mutual funds. Journal of Financial Economics 53, 439 - 466. 
Edelen, R., Warner, J., 2001. Aggregate price effects of institutional trading: A study of mutual fund flow and market returns. Journal of Financial Economics 59, 195-220.

Frazzini, A., Lamont, O., 2008. Dumb money: Mutual fund flows and the cross-section of stock returns. Journal of Financial Economics 88, 299-322,

Friesen, G., Sapp, T., 2007. Mutual fund flows and investor returns: An empirical examination of fund investor timing ability. Journal of Banking and Finance 31, 27962816.

Goetzmann, W., Massa, M., 2002. Daily momentum and contrarian behavior of index fund investors. Journal of Financial and Quantitative Analysis 37, 375-389.

Greene, J., Hodges, C., 2002. The dilution impact of daily fund flows on open-end mutual funds. Journal of Financial Economics 65, 131-158.

Gruber, M., 1996, Another puzzle: The growth in actively managed mutual funds. Journal of Finance 51, 783-810.

ICI. 2008 Investment Company Fact Book, 46 ${ }^{\text {th }}$ Edition, 2008. Investment Company Institute, www.icifactbook.org.

Jain, P., Wu, J., 2000. Truth in mutual fund advertising: Evidence on future performance and fund flows. Journal of Finance 55, 937-958.

Jayaraman, N., Khorana, A., Nelling, E., 2002. An analysis of the determinants and shareholder wealth effects of mutual fund mergers. Journal of Finance 57, 1521- 1551.

Johnson, W., 2007. Who monitors the mutual fund manager, new or old shareholders? Working paper, U.S. Securities and Exchange Commission.

Rakowski, D., 2009. Fund flow volatility and performance. Journal of Financial and Quantitative Analysis, forthcoming.

Shapira, Z., Venezia, I., 2001. Patterns of behavior of professionally managed and independent investors. Journal of Banking and Finance 25, 1573-1587.

Sirri, E., Tufano, P., 1998. Costly search and mutual fund flows. Journal of Finance 53, 1589-1622.

Venezia, I., Shapira, Z., 2007. On the behavioral differences between professional and amateur investors after the weekend. Journal of Banking and Finance 31: 1417-1426.

Wermers, R. 2000, Mutual fund performance: An empirical decomposition into stockpicking talent, style, transactions costs, and expenses. Journal of Finance 55, 1655-1695. 


\section{Table 1: Alternative Calculations of Daily Fund Flows:}

This table reports average daily fund flows computed by each of our three methods. Daily fund TNAs and returns between March 1, 2000 and October 31, 2006 are obtained from Lipper. Method 1 assumes day $t$ 's flows are not included in the reported $T N A_{t}$. Method 2 assumes the opposite. Method 3 matches the sum of daily dollar flows to monthly flow data from CRSP for each fund each month and selects the method which yields the smallest error. Sample funds include domestic equity, domestic bond, and international equity funds. Multiple share classes of the same fund are treated as separate funds. All flows are calculated using Method 3 in the following tables.

\begin{tabular}{lrrr} 
Average & Method 1 & Method 2 & Method 3 \\
\hline Daily Flow (\%) & 0.004 & 0.024 & 0.022 \\
Absolute Daily Flow (\%) & 0.526 & 0.475 & 0.475 \\
Daily Flow (\$thousands) & -17.102 & 17.571 & 15.836 \\
Absolute Daily Flow (\$) & 146.192 & 128.281 & 128.972 \\
Annualized Flow (\%) & 1.05 & 6.05 & 5.7 \\
Annualized Flow (\$millions) & -4.275 & 4.392 & 3.959 \\
\hline
\end{tabular}


This table reports the results for the following VAR estimation:

Table 2: VAR Results

$$
\left[\begin{array}{l}
r_{t} \\
f_{t}
\end{array}\right]=\left[\begin{array}{l}
\alpha_{1} \\
\alpha_{2}
\end{array}\right]+\sum_{p=1}^{L}\left[\begin{array}{ll}
\beta_{11, p} & \beta_{12, p} \\
\beta_{21, p} & \beta_{22, p}
\end{array}\right]\left[\begin{array}{c}
r_{t-p} \\
f_{t-p}
\end{array}\right]+\left[\begin{array}{l}
\varepsilon_{1, t} \\
\varepsilon_{2, t}
\end{array}\right]
$$

For daily data, the number of lags $(L)$ is chosen to be 5 and for monthly data, $L$ is chosen to be 12 . VAR estimation is run on each fund separately and reported are the average coefficient estimates and average $t$ values. Percentage of positive and negative significant coefficient estimates at the $95 \%$ level is also reported. For monthly estimation, the intercept has a 0 average estimate with an average $t$ value of 0.01 and no significant positive or negative estimates. To save space, it is not reported in the table.

Panel A: the Equation of Daily Flows

\begin{tabular}{lrrrrrrrrrrr}
\hline & Intercept & Retlag1 & Flowlag1 & Retlag2 & Flowlag2 & Retlag3 & Flowlag3 & Retlag4 & Flowlag4 & Retlag5 & Flowlag5 \\
\hline Average estimate & 0 & -0.03 & -0.30 & -0.02 & -0.10 & 0.00 & 0.00 & 0.01 & 0.00 & 0.00 & 0.03 \\
Average T-value & 0.00 & -1.02 & -8.26 & -0.71 & -2.66 & -0.16 & -0.12 & 0.23 & 0.12 & 0.17 & 0.86 \\
\% positive significant & 0 & 13 & 5 & 7 & 11 & 5 & 21 & 8 & 23 & 5 & 29 \\
\% negative significant & 0 & 39 & 74 & 25 & 55 & 9 & 25 & 3 \\
\hline
\end{tabular}

Panel B: the Equation of Monthly Flows

\begin{tabular}{|c|c|c|c|c|c|c|c|c|c|c|c|c|}
\hline & Retlag1 & Flowlag1 & Retlag2 & Flowlag2 & Retlag3 & Flowlag3 & Retlag4 & Flowlag4 & Retlag5 & Flowlag5 & Retlag6 & Flowlag6 \\
\hline Avg. estimate & 0.09 & 0.06 & 0.02 & 0.02 & 0.03 & 0.03 & -0.01 & -0.01 & 0.03 & 0.01 & 0.01 & -0.01 \\
\hline Average T-value & 0.54 & 0.33 & 0.15 & 0.1 & 0.19 & 0.16 & -0.07 & -0.05 & 0.24 & 0.04 & 0.09 & -0.08 \\
\hline$\%$ pos. and sig. & 13 & 18 & 5 & 7 & 5 & 6 & 3 & 3 & 6 & 4 & 4 & 3 \\
\hline \% neg. and sig. & 2 & 8 & 3 & 5 & 3 & 3 & 5 & 5 & 2 & 3 & 3 & 4 \\
\hline
\end{tabular}

\begin{tabular}{|c|c|c|c|c|c|c|c|c|c|c|c|c|}
\hline & Retlag7 & Flowlag7 & Retlag8 & Flowlag8 & Retlag9 & Flowlag9 & Retlag10 & Flowlag10 & Retlag11 & Flowlag11 & Retlag12 & Flowlag12 \\
\hline Avg. estimate & 0 & 0 & 0 & -0.02 & 0.01 & 0 & 0.02 & -0.01 & 0 & -0.01 & 0 & -0.01 \\
\hline Average T-value & -0.02 & 0.03 & 0.01 & -0.13 & 0.04 & 0.03 & 0.13 & -0.06 & 0.02 & -0.05 & -0.04 & -0.06 \\
\hline \% pos. and sig. & 4 & 4 & 4 & 3 & 4 & 4 & 4 & 3 & 4 & 3 & 3 & 4 \\
\hline \% neg. and sig. & 4 & 3 & 4 & 4 & 4 & 3 & 3 & 4 & 3 & 3 & 4 & 3 \\
\hline
\end{tabular}


Table 2: VAR Results, Continued

Panel C: the Equation of Daily Returns

\begin{tabular}{|c|c|c|c|c|c|c|c|c|c|c|c|}
\hline & Intercept & Retlag1 & Flowlag1 & Retlag2 & Flowlag2 & Retlag3 & Flowlag3 & Retlag4 & Flowlag4 & Retlag5 & Flowlag5 \\
\hline Average estimate & 0.00 & 0.05 & 0.05 & 0.02 & 0.17 & 0.01 & 0.06 & 0.02 & 0.01 & -0.02 & 0.00 \\
\hline Average T-value & 0.00 & 1.52 & 1.57 & 0.64 & 4.28 & 0.45 & 1.36 & 0.51 & 0.44 & -0.54 & -0.12 \\
\hline$\%$ positive significant & 0 & 44 & 45 & 32 & 61 & 20 & 42 & 9 & 17 & 2 & 3 \\
\hline$\%$ negative significant & 0 & 5 & 4 & 9 & 1 & 2 & 2 & 2 & 4 & 11 & 7 \\
\hline
\end{tabular}

Panel D: the Equation of Monthly Returns

\begin{tabular}{|c|c|c|c|c|c|c|c|c|c|c|c|c|}
\hline & Retlag1 & Flowlag1 & Retlag2 & Flowlag2 & Retlag3 & Flowlag3 & Retlag4 & Flowlag4 & Retlag5 & Flowlag5 & Retlag6 & Flowlag6 \\
\hline Ave. estimate & 0.08 & 0.00 & -0.11 & 0.00 & 0.00 & 0.00 & -0.14 & 0.00 & -0.01 & 0.00 & 0.01 & 0.00 \\
\hline Average T-value & 0.45 & -0.05 & -0.59 & 0.11 & 0.00 & -0.08 & -0.85 & -0.10 & -0.07 & 0.00 & 0.07 & -0.05 \\
\hline$\%$ pos. and sig. & 12 & 3 & 3 & 5 & 3 & 3 & 1 & 3 & 2 & 3 & 2 & 3 \\
\hline$\%$ neg. and sig. & 2 & 4 & 16 & 4 & 2 & 4 & 12 & 5 & 4 & 4 & 3 & 4 \\
\hline
\end{tabular}

\begin{tabular}{|c|c|c|c|c|c|c|c|c|c|c|c|c|}
\hline & Retlag7 & Flowlag7 & Retlag8 & Flowlag8 & Retlag9 & Flowlag9 & Retlag10 & Flowlag10 & Retlag11 & Flowlag11 & Retlag12 & Flowlag12 \\
\hline Ave. estimate & 0.01 & 0.00 & -0.01 & 0.00 & 0.00 & 0.00 & 0.02 & 0.00 & 0.03 & 0.00 & -0.04 & 0.00 \\
\hline Average T-value & 0.04 & 0.07 & -0.04 & -0.09 & -0.02 & -0.04 & 0.11 & -0.03 & 0.20 & -0.08 & -0.25 & -0.14 \\
\hline \% pos. and sig. & 3 & 4 & 2 & 3 & 3 & 4 & 3 & 3 & 2 & 3 & 2 & 3 \\
\hline \% neg. and sig. & 2 & 3 & 4 & 4 & 3 & 4 & 3 & 4 & 3 & 5 & 4 & 6 \\
\hline
\end{tabular}


Table 3: Seasonality in Daily Fund Flows

This table reports the average daily flows for the different periods in a month: beginning 5 days, last 5 days and Mid-month. It also reports the results for different days in a week. $* * *$ represents significance at the $99 \%$ level in t-tests for differences in means.

\begin{tabular}{lllllll} 
& First 5 days & Mid-Month & Last 5 days & Monday & Mid-week & Friday \\
\hline Daily Flow (\%) & $-0.018^{* * *}$ & $0.029^{* * *}$ & $0.031^{* * *}$ & $0.012^{* * *}$ & $0.030^{* * *}$ & 0.023 \\
|Daily Flow| (\%) & $0.490^{* * *}$ & $0.467 * * *$ & $0.493^{* * *}$ & $0.432^{* * *}$ & $0.433^{* * *}$ & $0.435^{* * *}$ \\
Daily Flow (\$ thousands) & $-113.96^{* * *}$ & $39.50^{* * *}$ & 44.65 & $-32.52^{* * *}$ & $30.78^{* * *}$ & 16.94 \\
Daily Return (\%) & $0.088^{* * *}$ & $-0.013^{* * *}$ & $0.101^{* * *}$ & $0.005^{* * *}$ & $0.021^{* * *}$ & $0.032^{* * *}$ \\
$\mathbf{N}$ & $1,017,196$ & $4,334,736$ & $1,139,011$ & $1,070,597$ & $3,450,796$ & $1,133,812$ \\
\hline
\end{tabular}




\section{Table 4: Descriptive Statistics of Daily Data}

This table presents descriptive statistics for the sample mutual funds by investment objective: domestic equity, domestic bond and international equity. Daily fund returns are from Lipper for the time period of March 2000 until October 2006, and daily flow calculations are explained in Table 1.

\begin{tabular}{lllll} 
& $\begin{array}{l}\text { All } \\
\text { Funds }\end{array}$ & $\begin{array}{l}\text { Domestic } \\
\text { Equity }\end{array}$ & $\begin{array}{l}\text { Domestic } \\
\text { Bond }\end{array}$ & $\begin{array}{l}\text { International } \\
\text { Equity }\end{array}$ \\
\hline Daily Flow (\%) & 0.021 & 0.023 & 0.011 & 0.038 \\
Annualized Daily Flow (\%) & 5.36 & 5.89 & 2.77 & 9.51 \\
Daily Flow (\$thousands) & 16.07 & 16.34 & -12.08 & 86.62 \\
Absolute Daily Flow (\%) & 0.475 & 0.568 & 0.255 & 0.621 \\
Daily Return (\%) & 0.022 & 0.021 & 0.02 & 0.029 \\
Annualized Daily Return (\%) & 5.65 & 5.49 & 5.23 & 7.42 \\
N & $6,456,767$ & $3,616,423$ & $2,039,525$ & 800,819 \\
\hline
\end{tabular}




\section{Table 5: Descriptive Statistics of Cross-sectional Characteristics}

This table reports the summary statistics of cross-sectional characteristics of the sample mutual funds. The daily RETURN is annualized, based on 250 trading days per year. Marketing expense is $12 B 1$ fee and management expense is NON12B1 fee. Loads are classified as FRONT and DEFERRED. TURNOVER is taken from the CRSP Mutual Fund database. SIZE is the fund's average daily TNA, in millions. AGE is the number of years from the inception of the fund. The size of a fund's family (FAMILY) is computed as the number of funds in the fund family.

\begin{tabular}{lllll} 
& $\begin{array}{l}\text { All } \\
\text { Funds }\end{array}$ & $\begin{array}{l}\text { Domestic } \\
\text { Equity }\end{array}$ & $\begin{array}{l}\text { Domestic } \\
\text { Bond }\end{array}$ & $\begin{array}{l}\text { International } \\
\text { Equity }\end{array}$ \\
\hline RETURN (\%) & 6.07 & 6.14 & 5.28 & 7.9 \\
12B-1 (\%) & 0.39 & 0.4 & 0.37 & 0.4 \\
NON 12B-1 (\%) & 0.99 & 1.09 & 0.7 & 1.36 \\
FRONT (\%) & 1.35 & 1.34 & 1.33 & 1.43 \\
DEFERRED (\%) & 1.11 & 1.12 & 1.09 & 1.12 \\
TURNOVER (\%) & 94.57 & 92.06 & 102.3 & 85.05 \\
SIZE & 266.34 & 299.5 & 199.24 & 299.66 \\
AGE & 9.72 & 9.41 & 10.58 & 8.8 \\
FAMILY & 146.01 & 135.27 & 159.99 & 155.95 \\
N & 6772 & 3688 & 2237 & 845 \\
\hline
\end{tabular}




\section{Table 6: Cross-Sectional Determinants of Daily Fund Flows}

Panel A presents results of regressions with mean daily percentage flow as the dependent variable. Panel B has the mean absolute daily percentage flow as the dependent variable. All explanatory variables are defined in Table 5. OLS coefficient estimates are presented. SIZE is entered as the natural log of the fund's average daily TNA. Both AGE and FAMILY are scaled by $1 / 100$ to ease comparison with other variables. $* *$ denotes significance at the $95 \%$ level and $* * *$ at the $99 \%$ level. The regression is:

$$
\begin{aligned}
& \text { Dependent }_{i}=\alpha+\beta_{0} \text { RETURN }_{i}+\beta_{1} \text { RETURN }_{i}^{2}+\beta_{2} 12 B 1_{i}+\beta_{3} N O N 12 B 1_{i}+\beta_{4} \text { FRONT }_{i}+\beta_{5} \text { DEFERRED }_{i}+\beta_{6} \text { TURNOVER }_{i}+\beta_{7} \text { SIZE }_{i}+ \\
& \beta_{8} A G E_{i}+\beta_{9} F A M I L Y_{i}+e_{i}
\end{aligned}
$$

\begin{tabular}{|c|c|c|c|c|c|c|c|}
\hline & $\begin{array}{l}\text { Domestic } \\
\text { Equity }\end{array}$ & $\begin{array}{l}\text { Domestic } \\
\text { Bond }\end{array}$ & $\begin{array}{l}\text { International } \\
\text { Equity }\end{array}$ & & $\begin{array}{l}\text { Domestic } \\
\text { Equity }\end{array}$ & $\begin{array}{l}\text { Domestic } \\
\text { Bond }\end{array}$ & $\begin{array}{l}\text { International } \\
\text { Equity }\end{array}$ \\
\hline Panel A & Dep=\%Flow & & & Panel B & Dep $=\mid \%$ Flow $\mid$ & & \\
\hline INTERCEPT & $0.0002 * *$ & 0.0002 & 0.0002 & INTERCEPT & $0.0058 * * *$ & $0.0033^{* * *}$ & $0.0064 * * *$ \\
\hline RETURN & $0.6255^{* * *}$ & $1.2766^{* * *}$ & $0.8800 * * *$ & RETURN & $2.5199 * * *$ & $-0.9844 * * *$ & $1.0165 * * *$ \\
\hline$R E T U R N^{2}$ & $293.7920 * * *$ & 789.7787 & $263.4771 * * *$ & $R_{E T U R N^{2}}$ & $659.5142 * * *$ & 1192.8048 & $1095.2694 * * *$ \\
\hline $12 B 1$ & $0.0126 * *$ & $0.0279 * * *$ & $0.0265 * *$ & $12 B 1$ & $0.0942 * * *$ & $0.0667 * * *$ & 0.0220 \\
\hline NON12B1 & 0.0020 & -0.0051 & -0.0087 & NON12B1 & $0.0231 * *$ & $0.0707 * * *$ & 0.0277 \\
\hline FRONT & $0.0027 * * *$ & 0.0010 & 0.0021 & FRONT & $0.0126^{* * *}$ & -0.0018 & $0.0218 * * *$ \\
\hline DEFERRED & $-0.0115^{* * *}$ & $-0.0086 * * *$ & $-0.0128 * * *$ & DEFERRED & $-0.0183 * * *$ & $-0.0184^{* * *}$ & $-0.0203 * * *$ \\
\hline TURNOVER & 0.0007 & 0.0018 & 0.0012 & TURNOVER & $0.0354 * * *$ & $0.0139 * * *$ & 0.0174 \\
\hline SIZE & $0.0052 * * *$ & 0.0014 & $0.0131 * * *$ & SIZE & $-0.0330 * * *$ & $-0.0225^{* * *}$ & $-0.0341^{* * *}$ \\
\hline$A G E$ & $-0.3086 * * *$ & $-0.4157 * * *$ & $-0.7035 * * *$ & $A G E$ & $-0.3411 * * *$ & $-0.2532 * * *$ & -0.1649 \\
\hline FAMILY & 0.0008 & 0.0001 & 0.0004 & FAMILY & $0.0187 * * *$ & 0.0009 & $0.0210^{* * *}$ \\
\hline Adjusted $\mathrm{R}^{2}$ & $19.51 \%$ & $11.47 \%$ & $33.14 \%$ & Adjusted $\mathrm{R}^{2}$ & $22.26 \%$ & $30.44 \%$ & $29.99 \%$ \\
\hline
\end{tabular}




\section{Table 7: Determinants of Flow Patterns}

This table presents coefficient estimates and chi-squared values (in parentheses) from probit regressions that analyze the probability that a fund will display persistence or mean-reversals in relation to lagged flow and momentum or contrarian behavior with regard to lagged returns. In the first (second) model, indicator takes a value of 1 if the coefficient estimate on flow at lag 1 was positive (negative) and significant in the flow equation in our VAR model. In the third (fourth) model, indicator takes a value of 1 if the coefficient estimate on returns at lag 1 was positive (negative) and significant in the flow equation in the VAR model. Dummy variables for international equity, domestic bond and domestic equity funds are included in the regressions. Domestic equity funds are further classified according to the four "corners" of Morningstar's 3x3 style box: small-cap, mid-cap or large-cap based on the capitalization of holdings, cross with value, core or growth orientation of the holdings. Other variables are explained in Table 5 . ** denotes significance at the $95 \%$ level and $* * *$ at the $99 \%$ level. The Probit regression is:

indicator $_{i}=\beta_{0}+\beta_{1} 12 B 1_{i}+\beta_{2}$ NON12B $1_{i}+\beta_{3}$ FRONT $_{i}+\beta_{4}$ DEFERRED $_{i}+\beta_{5}$ TURNOVER $_{i}+\beta_{6}$ SIZE $_{i}+\beta_{7}$ FAMILY $_{i}$

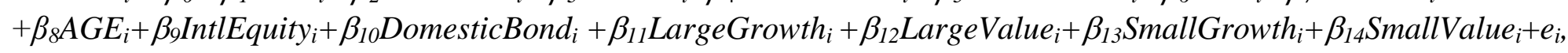

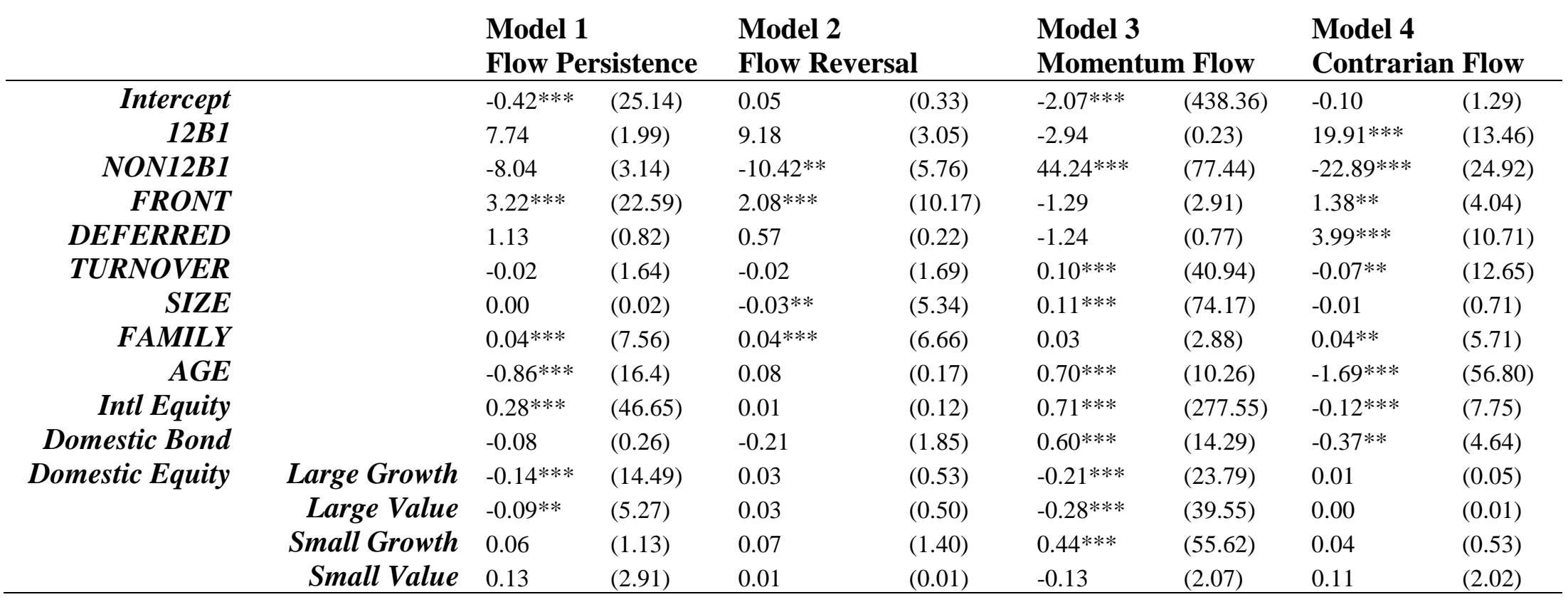

